\title{
O Brasil não é para amadores: Estado, governo e burocracia na terra do jeitinho
}

Alexandre Reis Rosa'

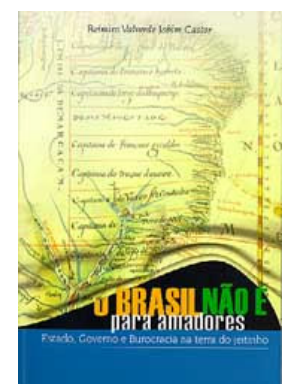

CASTOR, Belmiro Valverde Jobim. 0 Brasil não é para amadores: Estado, governo e burocracia na terra do jeitinho. 2. ed. rev. e aum. Curitiba: Travessa Editores, 2004. ISBN: 85-89485-08-0. 291p.

A realidade brasileira tem sido analisada sob a ótica de diversas áreas do conhecimento. Desde abordagens antropológicas até políticas, passando pelo enfoque econômico e sociológico, temos vários retratos do Brasil. A multiplicidade de interpretações nos fornece o arcabouço de um país híbrido e complexo que, por vezes, apresenta-se imerso nas próprias ambigüidades da sua formação histórica. Nesse sentido, a obra de Belmiro Valverde lança outro olhar sobre o Brasil, desta vez, do ponto de vista da administração.

Partindo do pressuposto de que, na experiência brasileira, o Estado precedeu a sociedade, deixando-a numa posição de obediência e submissão, o autor analisa seus desdobramentos e aponta suas consequiências para a conjuntura brasileira. Assim, a força política do Estado não foi canalizada para o desenvolvimento eqüitativo da sociedade, mas foi um catalisador das desigualdades sociais. Práticas como formalismo, clientelismo, patrimonialismo, improvisação e imediatismo encontraram terreno fértil para desenvolverem-se e caracterizarem o modus operandi de uma máquina estatal que, em última análise, administra os rumos da sociedade. $\mathrm{O}$ esforço do autor é no sentido de apresentar um modelo de análise que possibilite o entendimento da nossa realidade por meio da administração pública e suas nuanças no desenvolvimento social brasileiro. Para tanto, a discussão está dividida em três partes ao longo dos 12 capítulos que compõem o livro.

A primeira parte apresenta uma rica discussão sobre a herança lusitana de respeito reverencial pelo Estado, do fascínio pela proximidade do poder e da posição ambivalente diante do lucro. Essas características, ao longo de 500 anos, forjaram uma maneira mimética de estruturar nossas instituições. Destaca também a interação formalismo/jeitinho como forma de representar o espectro das relações da sociedade com o Estado. O culto da pessoalidade - caracterizado pela valorização do individual em detrimento do coletivo - leva a uma falta de coesão social e facilita o uso de expedientes alternativos para a satisfação de interesses privados. Assim, o formalismo estabelece regras com poder de veto e negação do individual, dando primazia ao coletivo, e o jeitinho se apresenta como uma estratégia de navegação social que visa driblar a regra (tida como meramente formal) e fazer prevalecer o interesse pessoal.

Na segunda parte, o autor sintetiza alguns aspectos da formação econômica, discutindo o capitalismo à brasileira. A partir das peculiaridades desse capitalismo e das suas relações com o Estado e com as empresas, temos a formação de um "capitalismo protegido" e de um "capitalismo público". Este, fruto de uma restrição da atividade industrial no período colonial, caracterizou-se pela presença do Estado na economia desde o Império, e, sobretudo, na república desenvolvimentista de Vargas, onde se justificava o Estado empresário com o discurso da incapacidade do setor privado de investir na infra-estrutura do país. Quanto ao "protegido", representado pelo setor privado, reflete uma relação umbilical com o Estado por meio de subsídios, vantagens fiscais e prote-

${ }^{1}$ Mestrando em Administração pelo Programa de Pós-Graduação em Administração da Universidade Federal de Lavras PPGA/UFLA. Endereço: Trav Nestor de Castro, 231 Bloco A - Apt 2102 - Centro - Curitiba - PR - Brasil - CEP: 800201 20. E-mail: alexandrereisrosa@hotmail.com. 
cionismo alfandegário. Dessa forma, a economia brasileira durante anos operou sob a tutela do Estado, até que no início dos anos 1990 a abertura econômica quebrou essa lógica, levando à bancarrota aqueles que, historicamente, caminhavam com a muleta do Estado.

Na terceira parte, o autor apresenta suas reflexões a respeito da administração brasileira e seus desencontros na formação de uma tradição gerencial, tanto no Estado como nas empresas. Sobre a mão-de-obra, critica a idéia de que abaixo dos trópicos as pessoas são indolentes e não muito adeptas a "ganhar o pão com o suor do rosto". Pois ao apresentar exemplos de outros países, revela que essa assertiva se trata de um mito que vem sendo alimentado em virtude da impontualidade do brasileiro e dos inúmeros feriados do nosso calendário. Sobre o setor público, destaca as diversas reformas administrativas que buscaram melhorar a eficiência do Estado. No entanto, todas foram marcadas por duas realidades: a primeira, pelo fato de que apesar de orientadas por objetivos globais e ambiciosos, sempre tiveram resultados parciais, melhorando alguns pontos e deixando vários intactos. Dessa forma, tivemos a improvisação como ferramenta básica para a solução de problemas, reestruturando o mínimo de operacionalidade com o menor desgaste político possível. A segunda realidade é que o processo de reforma sofre a ação de uma força antagônica de contra-reforma em que os avanços modernizantes esbarram na reação dos setores tradicionais que querem manter o poder político e burocrático.

Na parte final do livro, o autor conclui que a melhoria do Estado como mudança efetiva só seria bem-sucedida levando-se em conta uma vontade política por parte dos dirigentes. Com efeito, aponta a necessidade de se adotar uma visão lúcida, tanto do Estado como do mercado, para que uma perspectiva gerencial possa prevalecer na gestão pública. Propostas de gestão participativa, "emagrecimento" de estruturas governamentais, transparência e uso de tecnologia da informação são apresentadas como saídas viáveis para uma reforma do Estado.

Analisando $O$ Brasil não é para amadores: Estado, governo e burocracia na terra do jeitinho, pode-se afirmar que esse livro dá uma grande contribuição aos que se propõem a estudar a administração pública brasileira. A obra revela uma série de peculiaridades da nossa formação cultural, econômica e administrativa, o que ajuda o leitor a entender a dinâmica social desse país turbulento e ao mesmo tempo fascinante. Ademais, mostra também quão se faz necessário reformar a gestão pública, no sentido de torná-la efetivamente pública e com isso estancar as relações "intestinais" que marcam as instituições políticas e administrativas do Estado. No que diz respeito ao atual quadro político, isso acaba constituindo um locus privilegiado da corrupção e do tráfico de influências.

O ponto forte do livro reside na revisão bibliográfica de autores clássicos da nossa historiografia, como Gilberto Freyre, Celso Furtado e Raymundo Faoro. Tal iniciativa deu lastro à discussão e traçou um panorama enxuto da formação administrativa do Brasil. Dessa forma, no momento em que o país está quase completando 506 anos de existência, esta edição representa a oportunidade de uma releitura dos nossos erros e acertos. As entrelinhas do texto sinalizam para o leitor que o rumo do país deve contemplar uma clara noção dos limites e das possibilidades existentes, delineando-se a fronteira entre o Brasil desejável e o Brasil possível. 